\title{
Risk Assessment and Control Strategy of Residual Coal Pillar in Room Mining: Case Study in Ecologically Fragile Mining Areas, China
}

\author{
Hengfeng Liu ${ }^{1}$, Qiang Sun ${ }^{1,2, *}$, Nan Zhou ${ }^{1}$ and Zhongya $W^{1}{ }^{1}$ \\ 1 State Key Laboratory of Coal Resources and Safe Mining, School of Mines, China University of \\ Mining \& Technology, Xuzhou 221116, China; hengfengliu@cumt.edu.cn (H.L.); \\ ts20020075a31ld@cumt.edu.cn (N.Z.); zhongyawu@cumt.edu.cn (Z.W.) \\ 2 State Key Laboratory for Geomechanics and Deep Underground Engineering, China University of \\ Mining \& Technology, Xuzhou 221116, China \\ * Correspondence: kkysun@126.com; Tel.: +86-152-6201-0542
}

Citation: Liu, H.; Sun, Q.; Zhou, N.; $\mathrm{Wu}, \mathrm{Z}$. Risk Assessment and Control Strategy of Residual Coal Pillar in Room Mining: Case Study in Ecologically Fragile Mining Areas, China. Sustainability 2021, 13, 2712. https://doi.org/10.3390/su13052712

Academic Editor: Francesco Faccini

Received: 28 January 2021

Accepted: 26 February 2021

Published: 3 March 2021

Publisher's Note: MDPI stays neutral with regard to jurisdictional claims in published maps and institutional affiliations.

Copyright: (c) 2021 by the authors. Licensee MDPI, Basel, Switzerland. This article is an open access article distributed under the terms and conditions of the Creative Commons Attribution (CC BY) license (https:/ / creativecommons.org/licenses/by/ $4.0 /)$.

\begin{abstract}
Gradual instability of coal pillars left behind underground with room mining is one of the main reasons for sudden roof caving in the gob, surface subsidence, and other significant hazards. Moreover, room mining implies great losses of coal resources. In this paper, the main failure mode and room mining coal pillar process were analyzed according to the coalfield regional engineering geological and hydrogeological conditions. A numerical model was adopted to study the effect of different sizes of coal mining pillars and progressive instability failure of coal pillar on the plastic zone's evolution characteristics and stress field of coal pillars in the stope. The proposed technologies of cemented paste backfilling and reinforcement of residual coal pillars are applied, and a numerical simulation model is established to study the strata movement characteristics and analyze the stability degree of residual coal pillar and key aquiclude strata in the Pliocene series of Neogene. Consequently, the performance and application prospect were evaluated. The results obtained substantiate a new method for the long-term stability control of coal pillars in room mining and protecting the ecological environment in China's western eco-environmental frangible area.
\end{abstract}

Keywords: room mining; coal pillar stability; numerical modeling; coal pillar reinforcement; environmental protection

\section{Introduction}

The water resources of mining areas in western China are extremely short [1]. The degree of land desertification is high, the surface is covered with thick aeolian sand, the ecological environment system is very fragile, and soil erosion is very serious [2]. At the end of the 20th century, the room and pillar (R\&P) mining method was widely used in the western coal resources, and many coal pillars remained in the goaf $[3,4]$. With the mining area's extension and passage of time, the remaining coal pillars' fracture and instability will cause the goaf roof to collapse in a large area, inducing mine tremors and shock waves. The goaf surface has a large number of subsidence areas. At the same time, it is easy to cause the mining fractures of overburden rock to expand from the bottom to the top and directly communicate with the surface, resulting in the leakage of shallow water and groundwater [5]. This would destroy the vegetation on the surface and imply land desertification and other environmental hazards, deteriorating the originally fragile ecological environment system [6-8] (Figure 1). The long-term stability control of coal pillars is one of the main challenges in room mining [9]. Therefore, this issue must be addressed to protect the economic and social development of western China. 


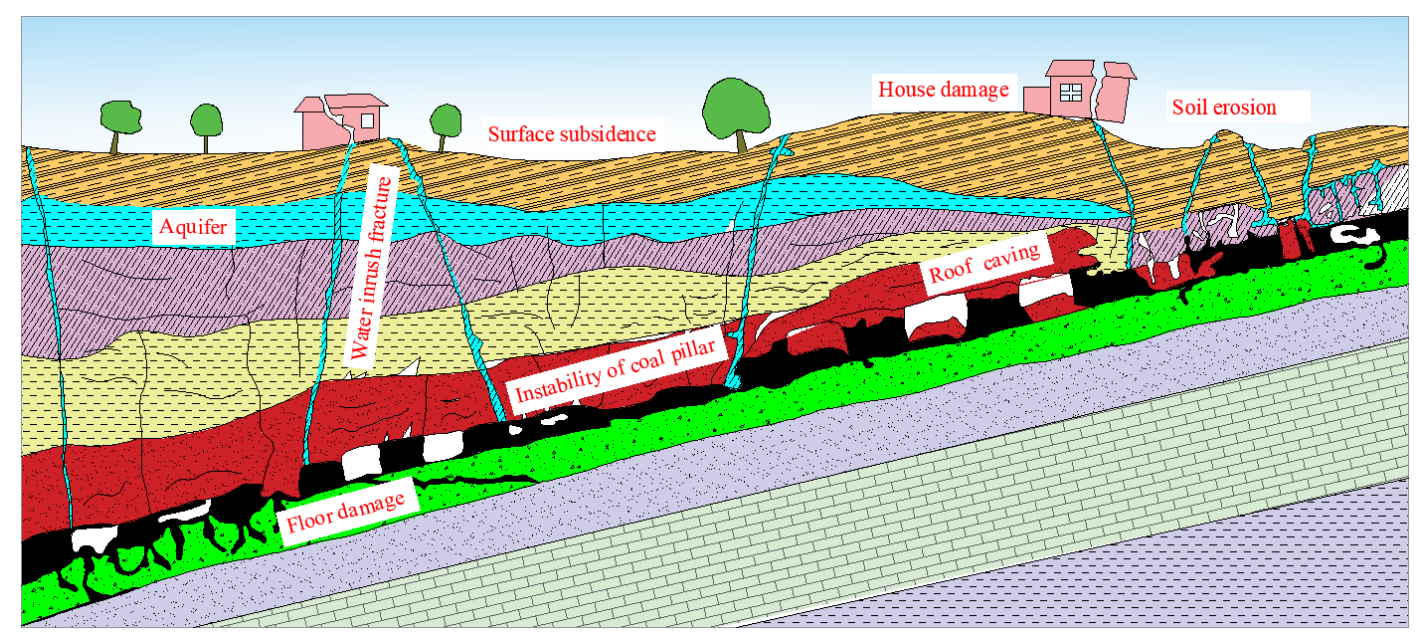

Figure 1. Schematic diagram environmental destructions and problems caused by room mining.

In the past decades, the backfill mining technology, which offers economic and environmental benefits, has been used extensively in China's underground mines. An [10] presented the framework and detailed method to retreat room mining standing pillars with consolidated solid backfilling mining (SBM). Alternatively, Fang [11] proposed a new method to extract the remaining coal pillar by replacing it with an artificial pillar based on SBM technology. This approach envisaged a comprehensive account of cemented material's mechanical characteristics, the development of an overlying strata support system, and strata behavior under different sizes and intervals of artificial pillars, which should be validated by laboratory tests, theoretical analysis, and numerical simulation results. Finally, it implied the engineering design of recovering room coal pillars based on the western China mining area's geological conditions. A previous study, which included two coauthors of the present paper [12], investigated the plastic zone and stress evolution of coal pillar in stope during short-strip coal pillar recovery with cemented paste backfill (CPB) and proposed to utilize the remaining coal pillar with aeolian sand as the main backfill material. Aiming at the treatment of permanent ground fractures caused by mining, based on the test of physical and mechanical properties of ultra-high-water materials, the field filling technology and filling system of ultra-high-water materials were also developed. A three-step method of ground fissure treatment of "deep filling, surface soil covering, and vegetation greening" was put forward by Liu et al. [13].

However, because of the difference between the backfill materials' and filling costs, no rapid backfilling coal mining method suitable for wide use in China's local coal mines has been proposed and validated yet. Backfill materials (tailings and gangues) are not very abundant because of the special mining and geological conditions in western China. The resultant high cost of backfill greatly limits the SBM application. Because aeolian sand is found abundantly in the local mining area, it is considered quite expedient to use CPB materials associated with aeolian sand to control residual coal pillars' long-term stability. In this study, the influencing factors of coal pillar stability in room mining are analyzed. The evolution patterns of stresses and plastic zone of coal pillars in stope are studied. The regional reinforcement method of coal pillar is proposed, and a relevant case study proves its feasibility.

\section{Background}

\subsection{The Coal Mine Case Study}

The case study is performed for the coal mine located in the Dongsheng Coalfield, Inner Mongolia Autonomous Region, China, which belongs to the North China stratigraphic region and Ordos stratigraphic division. Most of the coalfield is covered by aeolian sand and loess. According to the ground geology and drilling data, the strata in the area 
are, from old to new: Upper Triassic Yanchang Formation $\left(\mathrm{T}_{3 \mathrm{y}}\right)$, Middle-Lower Jurassic Yan'an formation $\left(\mathrm{J}_{1-2 \mathrm{y}}\right)$, Middle Jurassic Zhiluo Formation $\left(\mathrm{J}_{2 \mathrm{Z}}\right)$, Middle Jurassic Anding formation $\left(\mathrm{J}_{2 \mathrm{~A}}\right)$, Upper Jurassic Lower Cretaceous Zhidan group $\left(\mathrm{J}_{3}-\mathrm{K}_{1 \mathrm{zh}}\right)$, Tertiary $\left(\mathrm{N}_{2}\right)$, and Quaternary $(\mathrm{Q})$, respectively. The coalfield area is $20.96 \mathrm{~km}^{2}, 6.54 \mathrm{~km}$ long from east to west and $4.665 \mathrm{~km}$ wide from north to south.

The main coal seam is located in the lower part of the middle and lower Jurassic Yan'an formation $\left(\mathrm{J}_{1-2 \mathrm{y}}\right)$. The coal seam thickness is $5.35-6.95 \mathrm{~m}$, with an average of $6.0 \mathrm{~m}$. The coal seam structure is simple, without gangue or with 1-2 layers of gangue. The lithology is generally mudstone and carbonaceous mudstone. The coal seam's roof lithology is sandy mudstone, mudstone, fine sandstone, and siltstone. The floor lithology is siltstone, mudstone, and sandy mudstone. The compressive strength of the minable coal seam's immediate roof is between 17.4 and $19.2 \mathrm{MPa}$, and that of the floor ranges between 16.1 and 17.2 MPa. Although the main soft rock is soft, the structural plane is not developed, and the rock quality designation (RQD) value is between 50 and $90 \%$. The rock quality is good, and the rock mass is relatively complete. The room coal mining method was adopted for coal production and the coal pillar support method was utilized for roof management. After the coal mine under study was put into operation, 8.21 million tons of raw coal have been mined, and the recovery rate was only $31 \%$. Furthermore, large coal pillars were left behind in the mining area, some of them being unstable at the early mining stage, and thus, they failed after long-term loading. In some areas, the roof had even caved into the gob. Given this, it is critical to ensure the coal pillar's stability in the mined-out area to achieve sustainable production of the mine, protect local water resources, and satisfy other environmental requirements. The panel layout of the study area is depicted in Figure 2.

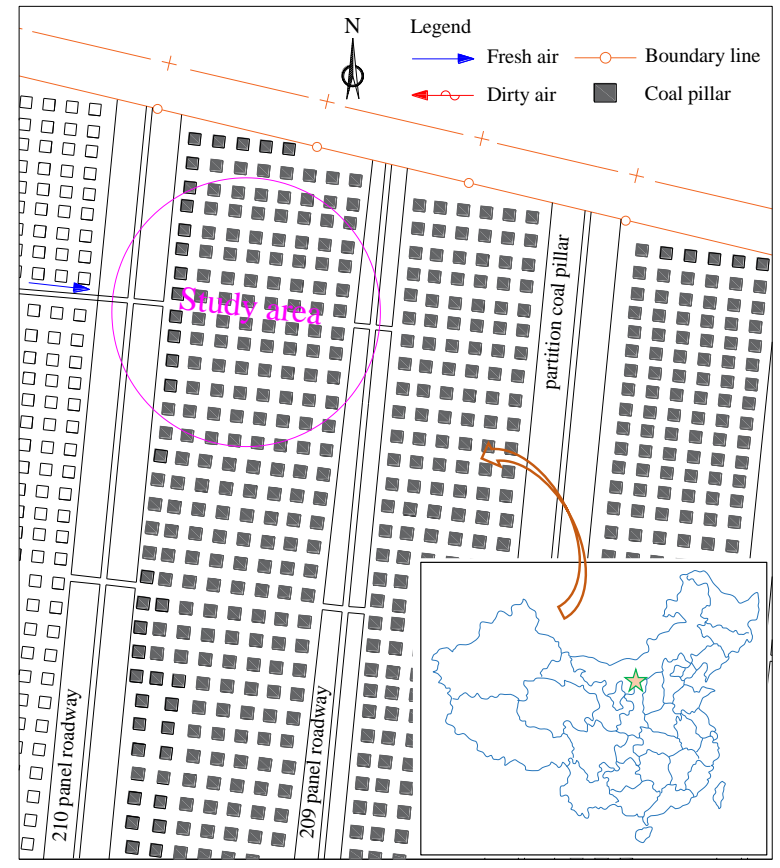

(a)

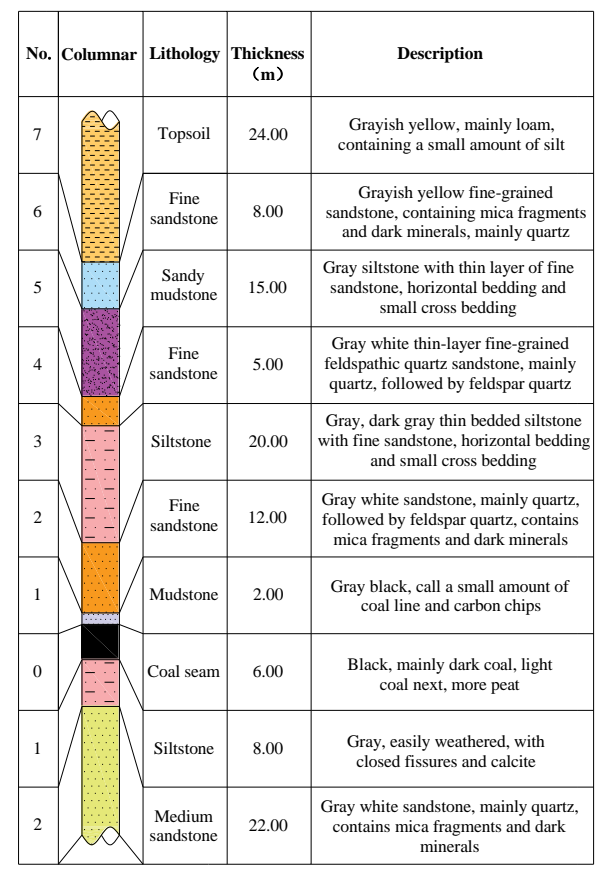

(b)

Figure 2. The panel layout of the study area: (a) plane view; (b) the generalized stratigraphic column.

\subsection{Failure Mode and Process of Room Mining Coal Pillar}

With the coal seam's continuous room mining, the coal pillar's lateral stress is gradually relieved, and the pressure of the overlying strata is gradually transferred to the coal pillar, increasing compressive stresses and strains. The coal pillar's overall response to the stress redistribution in room mining depends on the dimensions (length, width, and height), shape, and internal structure of the coal pillar. According to the field investigation 
results, there are mainly six kinds of failure modes of room coal pillars [14], as shown in Figure 3.

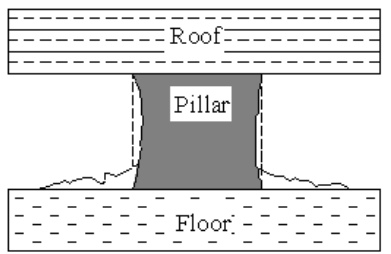

(a)

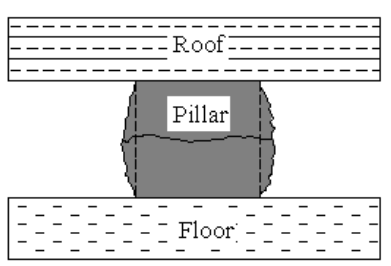

(d)

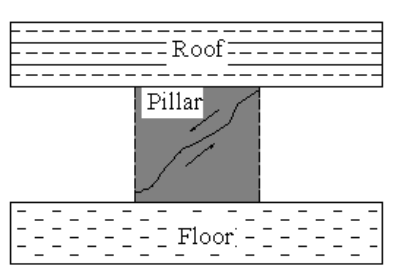

(b)

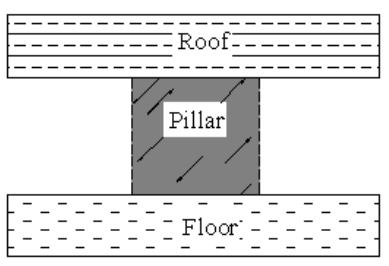

(e)

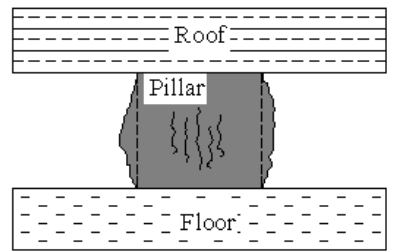

(c)

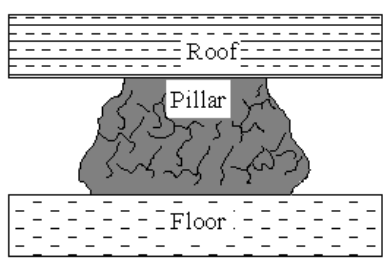

(f)

Figure 3. Main failure modes of coal pillars: (a) lateral spalling; (b) compression-shear failure; (c) splitting inside pillar; (d) joint failure; (e) flexural failure; (f) collapse damage.

The room mining coal pillar's instability and failure occur as a gradual process, depicted in Figure 4. According to the distribution pattern of stress (vertical direction) in the coal pillar, a toroidal type (Figure $4 \mathrm{~b}, \mathrm{c}$ ) is a typical sign of the coal pillar's stable state. When the toroidal type is transformed into the central platform type (Figure $4 \mathrm{~d}$ ), the coal pillar enters the accelerated failure stage, making the central platform type an important turning point in the critical state of instability. With a gradual reduction of the elastic core area of the coal pillar, the latter undergoes five states from the initial one to instability [15], which features the corresponding five stress distribution patterns: wide toroidal type, narrow toroidal type, central platform type, sharp peak type (Figure 4e), and blunt peak type (Figure $4 \mathrm{f})$.
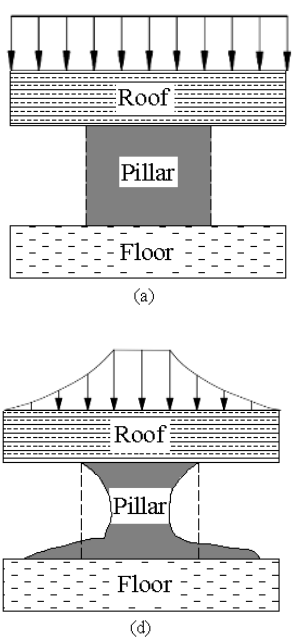
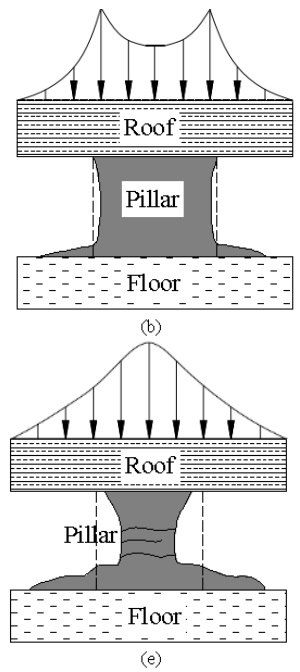
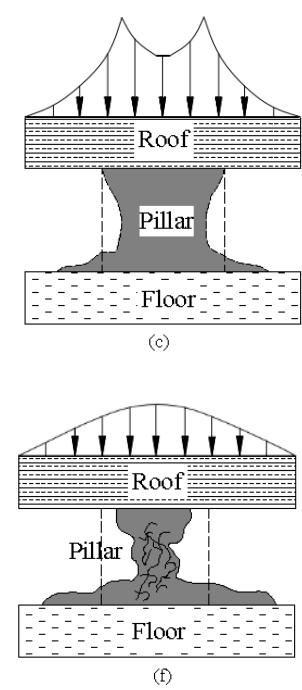

Figure 4. Failure process of room mining coal pillar: (a) initial state, (b) wide toroidal type, (c) narrow toroidal type, (d) central platform type, (e) sharp peak type, (f) blunt peak type.

Some researchers $[16,17]$ reported that the coal pillar under the toroidal type load mode has high stability, and the central platform type load form is the turning point between the coal pillar's stability and instability. A relatively stable state of the coal pillar is then violated, and an accelerated instability stage is observed. 


\section{Stability Analysis of the Residual Coal Pillar in Room Mining}

\subsection{Global Model and Simulation Plans}

The FLAC ${ }^{3 \mathrm{D}} 5.0$ software package, developed by Itasca Consulting Group, Inc. (Minneapolis, MN, USA) and widely used in mining engineering, was implemented in this study using the conventional Mohr-Coulomb model of coal and rock damage [18-20]. Based on the case study's geological conditions, the numerical model assumed a length of $281 \mathrm{~m}$ in the dip direction, a width of $185 \mathrm{~m}$ in the strike direction, and a height of $122 \mathrm{~m}$ area (Figure 5a). The horizontal displacements of four vertical planes of the model were restricted in the normal direction, and the vertical displacement at the base of the model was set to zero. The elastic and shear moduli could be derived via the stress-strain relationship. Different parameters were employed, adjusted, and scaled in a laboratory to determine rock and coal samples' mechanical properties. The final physical and mechanical parameters of rock in numerical simulations are presented in Table 1.

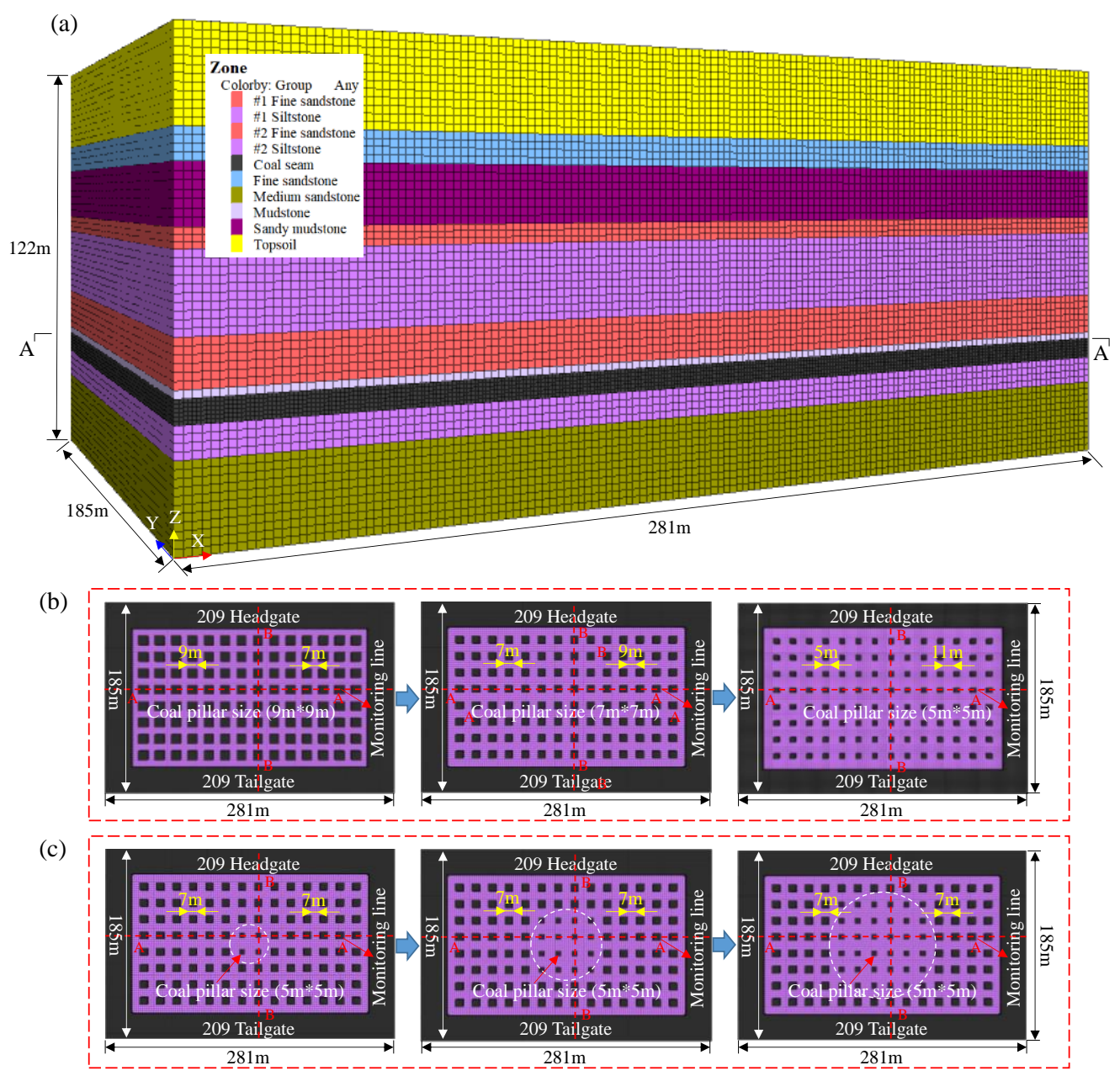

Figure 5. Numerical model and the excavation simulation process: (a) model size, (b) the first mining scheme, (c) the second mining scheme. 
Table 1. Physical and mechanical parameters of rocks in numerical simulations.

\begin{tabular}{|c|c|c|c|c|c|c|}
\hline Strata & $\begin{array}{l}\text { Bulk Modulus } \\
\text { (GPa) }\end{array}$ & $\begin{array}{l}\text { Shear Modulus } \\
\text { (GPa) }\end{array}$ & $\begin{array}{c}\text { Cohesion } \\
\text { (MPa) }\end{array}$ & $\begin{array}{c}\text { Tensile Strength } \\
\text { (MPa) }\end{array}$ & $\begin{array}{l}\text { Internal Friction } \\
\text { Angle (Degrees) }\end{array}$ & $\begin{array}{c}\text { Density } \\
\left(\mathrm{kg} \cdot \mathrm{m}^{-3}\right)\end{array}$ \\
\hline Topsoil & 0.04 & 0.02 & 0.35 & 0.5 & 26 & 1900 \\
\hline Fine sandstone & 1.8 & 1.4 & 1.2 & 0.6 & 22 & 1600 \\
\hline Sandy mudstone & 0.3 & 0.2 & 0.5 & 0.05 & 30 & 1880 \\
\hline Fine sandstone & 1.8 & 1.4 & 1.2 & 0.6 & 22 & 1600 \\
\hline Siltstone & 4.5 & 3.2 & 2.5 & 1.1 & 30 & 2600 \\
\hline Fine sandstone & 5.8 & 3.8 & 3.2 & 2.7 & 33 & 2360 \\
\hline Mudstone & 4.2 & 2.6 & 1.5 & 2.1 & 28 & 2280 \\
\hline Coal seam & 3.2 & 1.8 & 0.8 & 1.7 & 25 & 1400 \\
\hline Siltstone & 4.2 & 2.6 & 1.5 & 2.1 & 32 & 2180 \\
\hline Medium Sandstone & 6.5 & 4.8 & 2.5 & 2.5 & 36 & 2600 \\
\hline
\end{tabular}

The numerical simulation process can be reduced to (i) calculating the initial state induced by gravity and (ii) simulating the room's excavation. This paper focuses on the influence of different sizes of coal mining pillars and progressive instability failure of coal pillar on strata movement in the stope. The first mining scheme covers mining rooms with sizes of $7 \mathrm{~m} \times 7 \mathrm{~m}, 9 \mathrm{~m} \times 9 \mathrm{~m}$, and $11 \mathrm{~m} \times 11 \mathrm{~m}$; a room pillar of $9 \mathrm{~m} \times 9 \mathrm{~m}, 7 \mathrm{~m} \times 7 \mathrm{~m}$, and $5 \mathrm{~m} \times 5 \mathrm{~m}$ sizes is left behind underground. The second mining scheme implies a mining room with a size of $9 \mathrm{~m} \times 9 \mathrm{~m}$, while the room pillar has the initial size of $7 \mathrm{~m} \times 7 \mathrm{~m}$, which is then reduced to $5 \mathrm{~m} \times 5 \mathrm{~m}$ from the stope middle to the boundary. The specific process of excavation simulation is depicted in Figure $5 b$.

\subsection{Numerical Simulation Results}

The characteristics of the plastic zone and stress distribution in stope with different room pillar sizes of $9 \mathrm{~m} \times 9 \mathrm{~m}, 7 \mathrm{~m} \times 7 \mathrm{~m}$, and $5 \mathrm{~m} \times 5 \mathrm{~m}$ were obtained through numerical simulation, as shown in Figure 6. The middle profile stresses in left-behind coal pillars were selected to analyze room mining development and stability, as shown in Figure 7. The plastic zone distribution during coal pillar size evolution from $9 \mathrm{~m} \times 9 \mathrm{~m}$ to $5 \mathrm{~m} \times 5 \mathrm{~m}$ is depicted in Figure 8.

The numerical simulation of room mining shows that the coal pillar's failure gradually occurs from the outside to the inside. The coal pillar's peak stress increases from 6.7 to $10.5 \mathrm{MPa}$ with a size reduction from $9 \mathrm{~m} \times 9 \mathrm{~m}$ to $7 \mathrm{~m} \times 7 \mathrm{~m}$. Then, the peak stress drops to $8.0 \mathrm{MPa}$ at the pillar size of $5 \mathrm{~m} \times 5 \mathrm{~m}$. The boundary coal pillar's peak stress changes from 4.1 to $5.9 \mathrm{MPa}$ and then increases to $7.0 \mathrm{MPa}$. The reason is that the coal pillar area decreases, and the overlying load increases. When the coal pillar fails, the overlying load is transferred to the boundary pillar. Moreover, compared with the middle part of the coal pillars, the boundary pillars' failure time is delayed.

The characteristics of the plastic zone and stress distribution in stope with the gradual increase of the scope of small-sized coal pillars $(5 \mathrm{~m} \times 5 \mathrm{~m})$ were obtained through numerical simulation, as shown in Figure 9. The middle profile of left-behind coal pillars' stress was selected to analyze room mining development and stability, as shown in Figure 10. The plastic zone distribution of boundary coal pillars during the gradual increase of small-size coal pillars' scope is shown in Figure 11. 

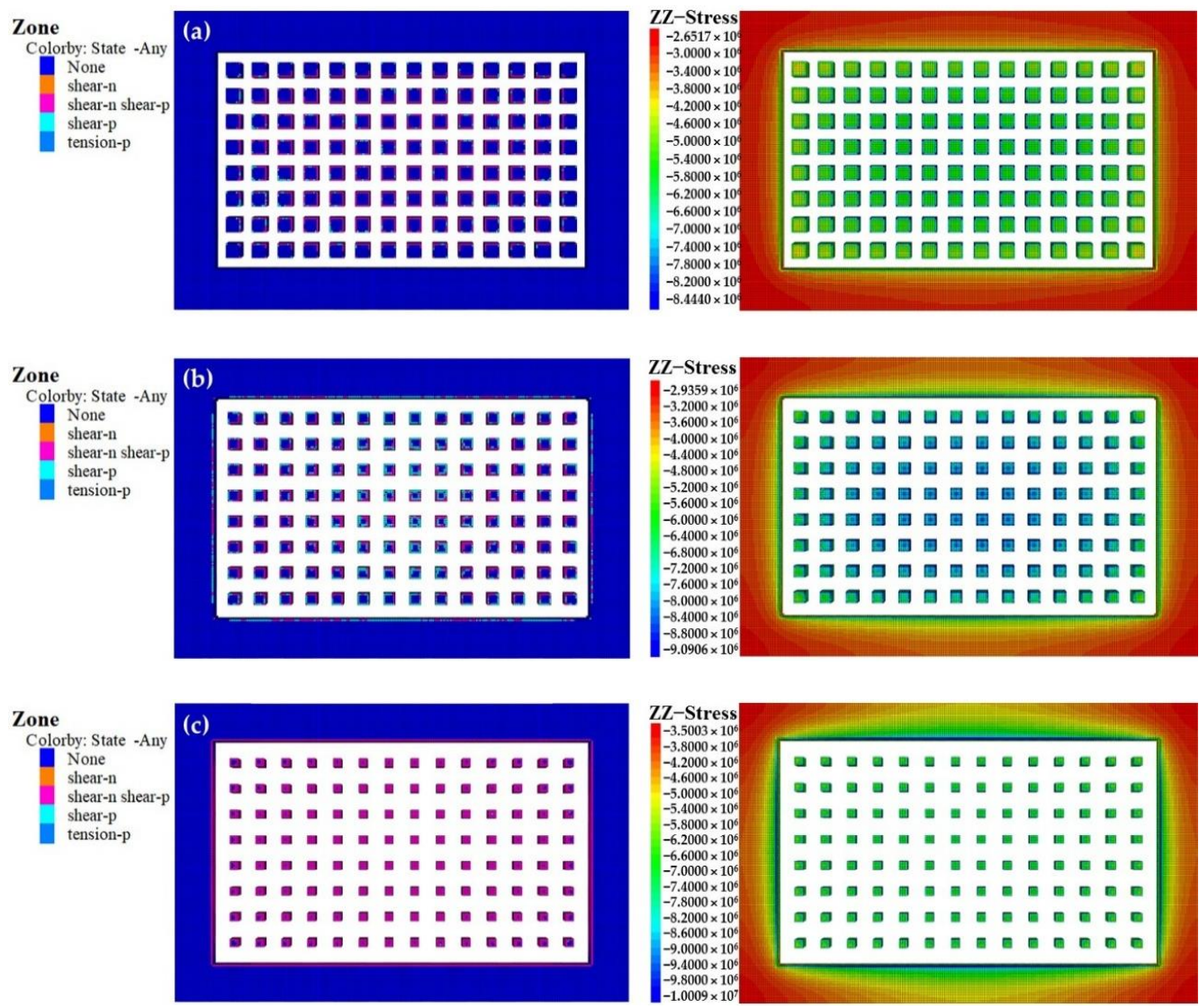

Figure 6. Characteristics of the plastic zone and stress distribution in the stope with different room pillar sizes: (a) $9 \mathrm{~m} \times 9 \mathrm{~m}$; (b) $7 \mathrm{~m} \times 7 \mathrm{~m}$; (c) $5 \mathrm{~m} \times 5 \mathrm{~m}$.
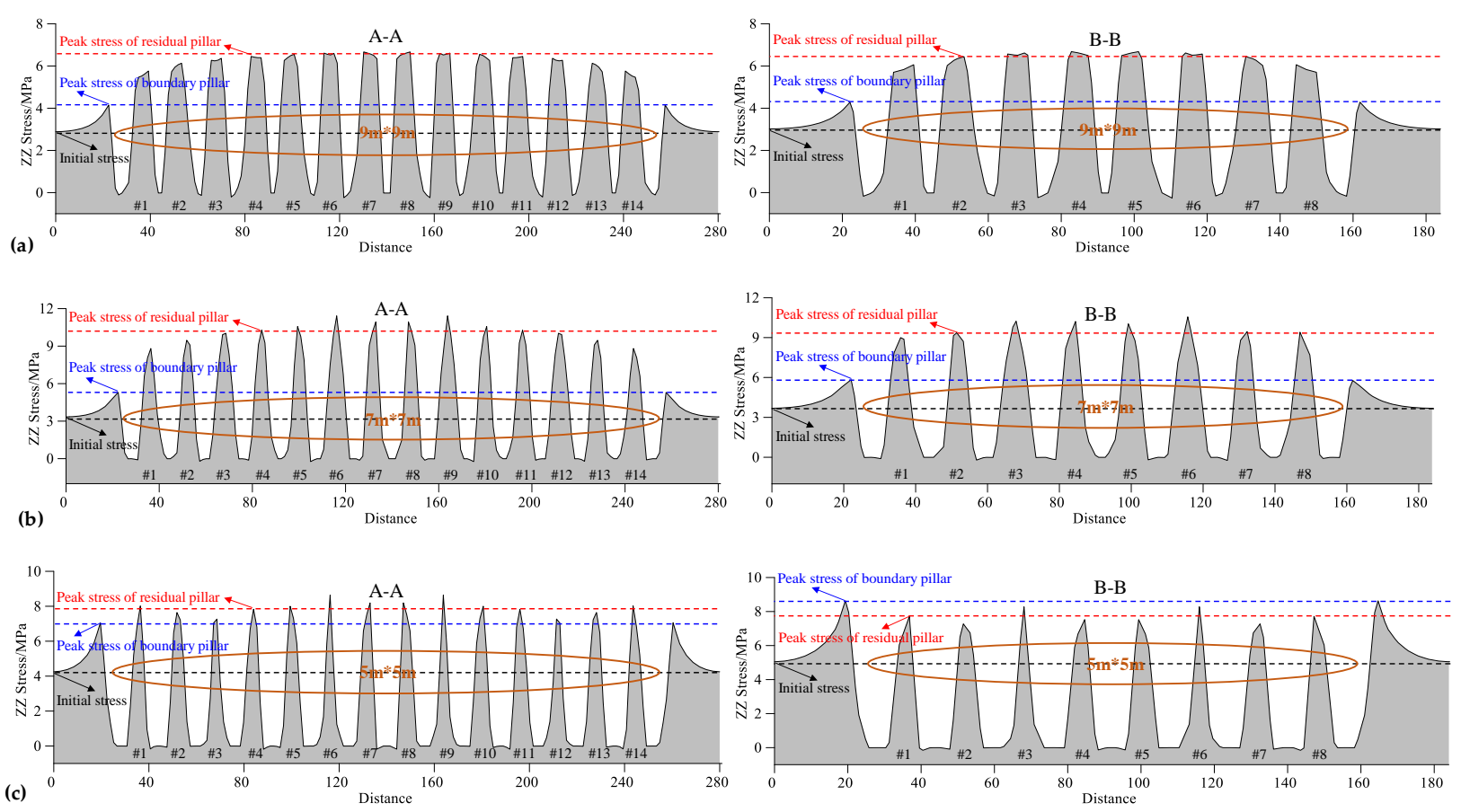

Figure 7. Profile of stress distribution characteristics of coal pillars in the middle of stope with different sizes: (a) $9 \mathrm{~m} \times 9 \mathrm{~m}$; (b) $7 \mathrm{~m} \times 7 \mathrm{~m}$; (c) $5 \mathrm{~m} \times 5 \mathrm{~m}$. 

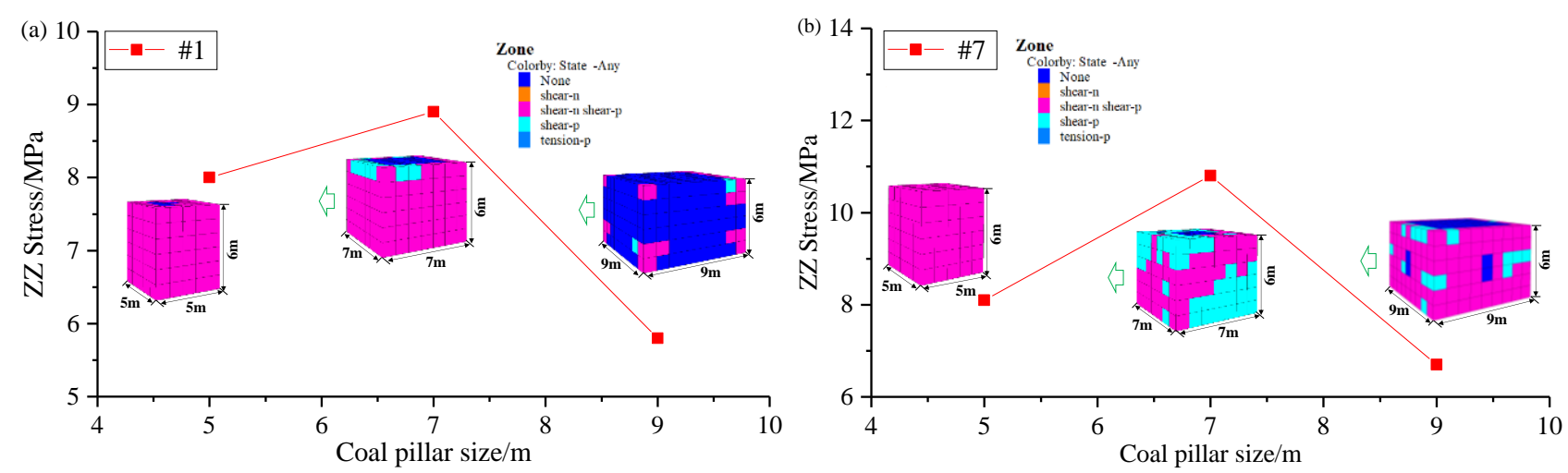

Figure 8. Plastic zone distribution during the coal pillar size reduction: (a) \#1 coal pillar; (b) \#7 coal pillar.
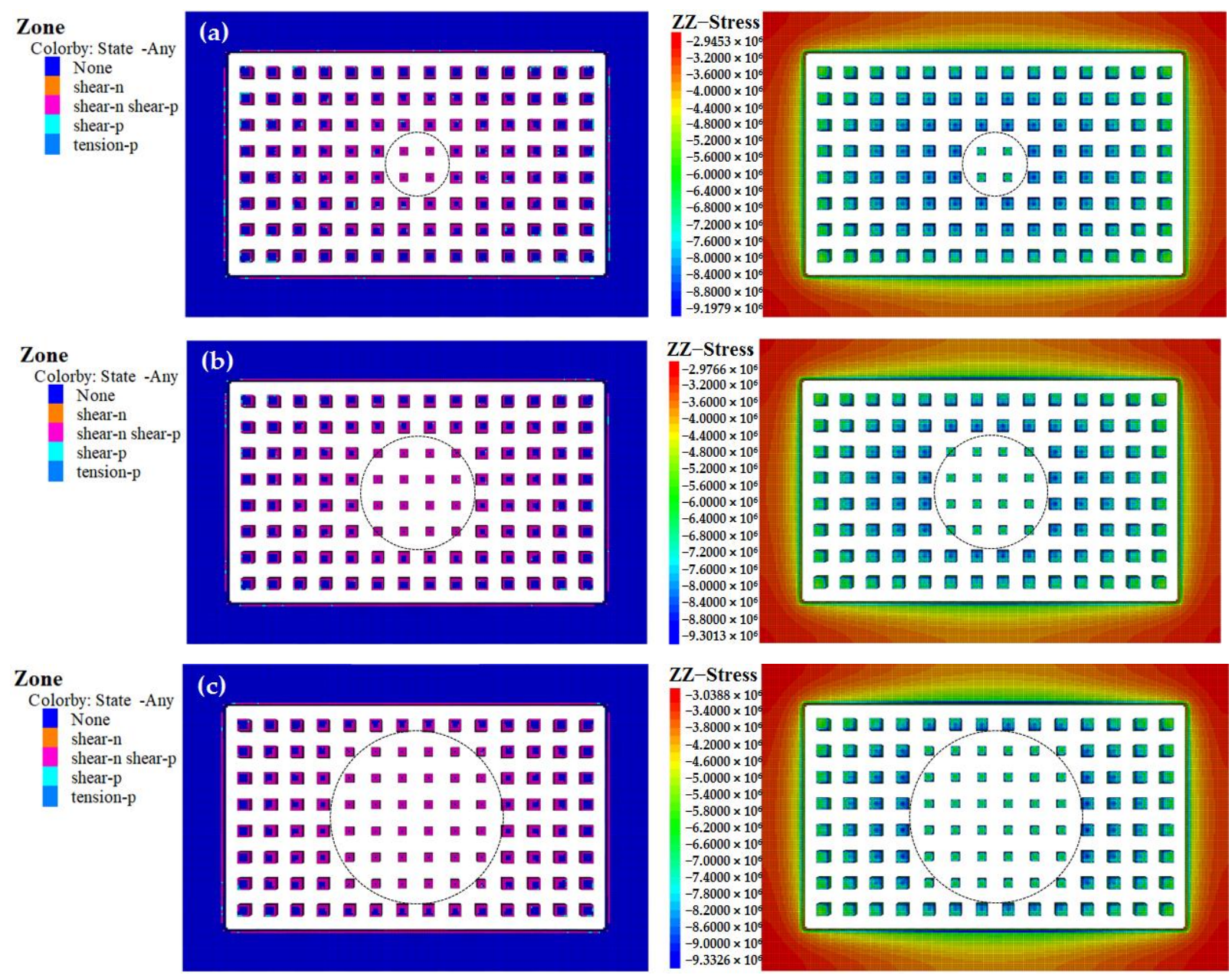

Figure 9. Characteristics of the plastic zone and stress distribution in stope with a gradual increase in the scope of small-sized coal pillars: (a) 4 coal pillars with $5 \mathrm{~m} \times 5 \mathrm{~m}$; (b) 16 coal pillars with $5 \mathrm{~m} \times 5 \mathrm{~m}$; (c) 36 coal pillars with $5 \mathrm{~m} \times 5 \mathrm{~m}$. 

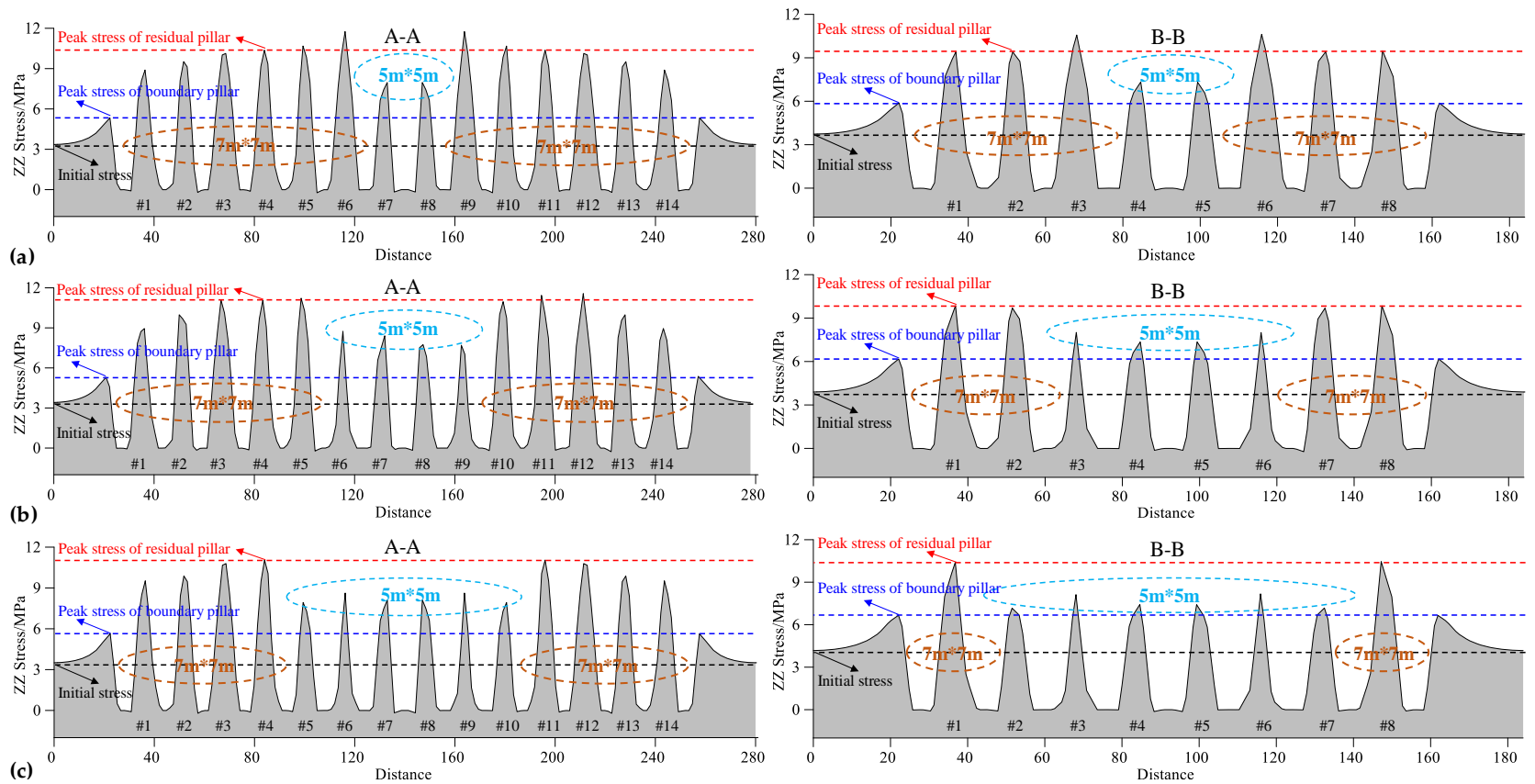

Figure 10. Profile of stress distribution characteristics of coal pillars in the middle of stope with a gradual increase in the scope of small-sized coal pillars: (a) 4 coal pillars with $5 \mathrm{~m} \times 5 \mathrm{~m}$; (b) 16 coal pillars with $5 \mathrm{~m} \times 5 \mathrm{~m}$; (c) 36 coal pillars with $5 \mathrm{~m} \times 5 \mathrm{~m}$.
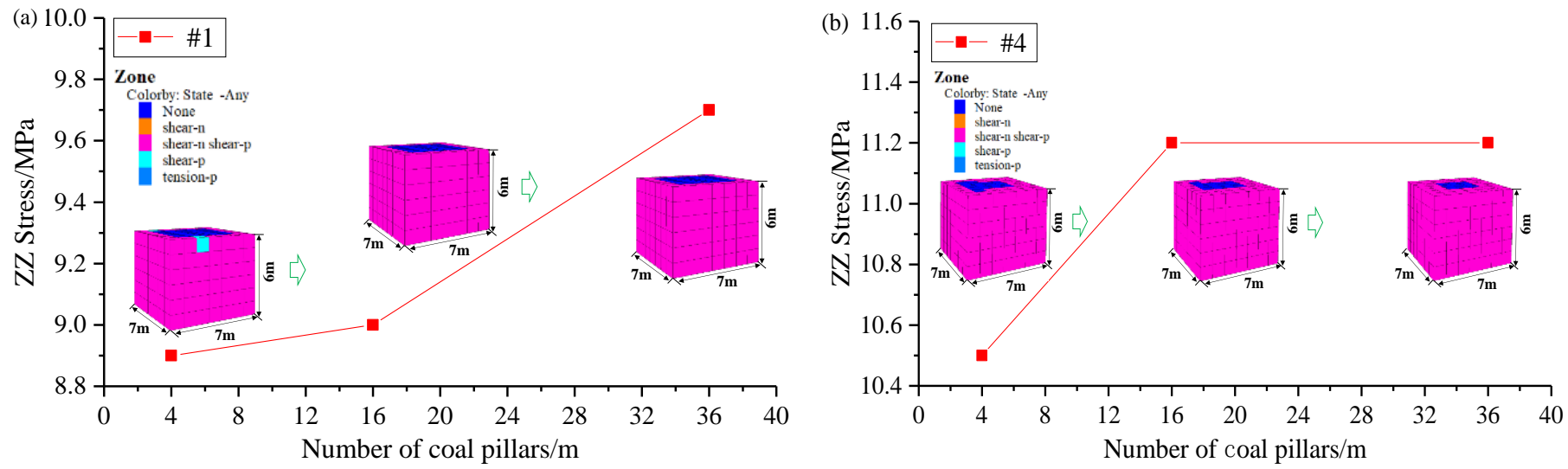

Figure 11. Plastic zone distribution with a gradual increase in the scope of small-sized boundary coal pillars: (a) \#1 coal pillar; (b) \#4 coal pillar.

The room mining process's numerical simulation revealed that the peak stress in the boundary coal pillar increased with a gradual increase in small-sized coal pillars' scope. The overlying loads of $7 \mathrm{~m} \times 7 \mathrm{~m}$ coal pillars exceeded those of $5 \mathrm{~m} \times 5 \mathrm{~m}$ ones. The reason is that with a gradual increase in the scope of small-sized coal pillars, the failure of coal pillars with a size of $5 \mathrm{~m} \times 5 \mathrm{~m}$ occurs, and the overlying load is transferred to the large coal pillars nearby. Although the boundary pillar's failure range is relatively small, with an increase in the number of unstable coal pillars, the roof's effective bearing capacity will deteriorate. The suspended roof area will increase; when the breaking limit is reached, the roof will collapse in a large area. It will bring dynamic disasters of roof movement and surface subsidence, as well as other environmental damages. 


\section{Reinforcement Method of Residual Coal Pillars in Room Mining \\ 4.1. Overall Method and Simulation Plans}

The water resources are seriously deficient in the ecologically fragile western area of China. The stability of the key water-resisting layer in the Pliocene series of Neogene can effectively prevent the disaster of pore phreatic water of Quaternary and the surface water from inrushing underground, thereby protecting the local environment. The key measure is to ensure the residual coal pillar's stability after room mining to solve the above problems. In this study, cemented paste backfilling (CPB) technologies on the ground and reinforcement of residual coal pillars were proposed. The main idea was to use mixed cementation materials, such as aeolian sand, crushed gangue, fly ash, cement, etc., and reinforce the residual coal pillar in a specific area on the ground by pump backfilling (Figure 12a). In this paper, the proportion of CPB is as follows: aeolian sand (62.6\%), fly ash $(28.9 \%)$, ordinary Portland cement $42.5 \mathrm{R}(8.5 \%)$, and water/cement ratio (4.7); the detail mechanical parameters of the backfill materials can be seen in the reference [12]. The numerical simulation model was established to further study the strata movement characteristics and analyze the stability degree of residual coal pillar and key aquiclude strata. The model dimensions were as follows (Figure 12b): a length of $409 \mathrm{~m}$ in the dip direction, a width of $185 \mathrm{~m}$ in the strike direction, and a height of $122 \mathrm{~m}$. The mining room size was $9 \mathrm{~m} \times 9 \mathrm{~m}$, the residual coal pillar after room mining was $7 \mathrm{~m} \times 7 \mathrm{~m}$. The number of residual coal pillars reinforcement was set at 16 . The space between ground pump backfilling stations was $160 \mathrm{~m}$, according to the measured data of key strata breaking and movement in the local mine.
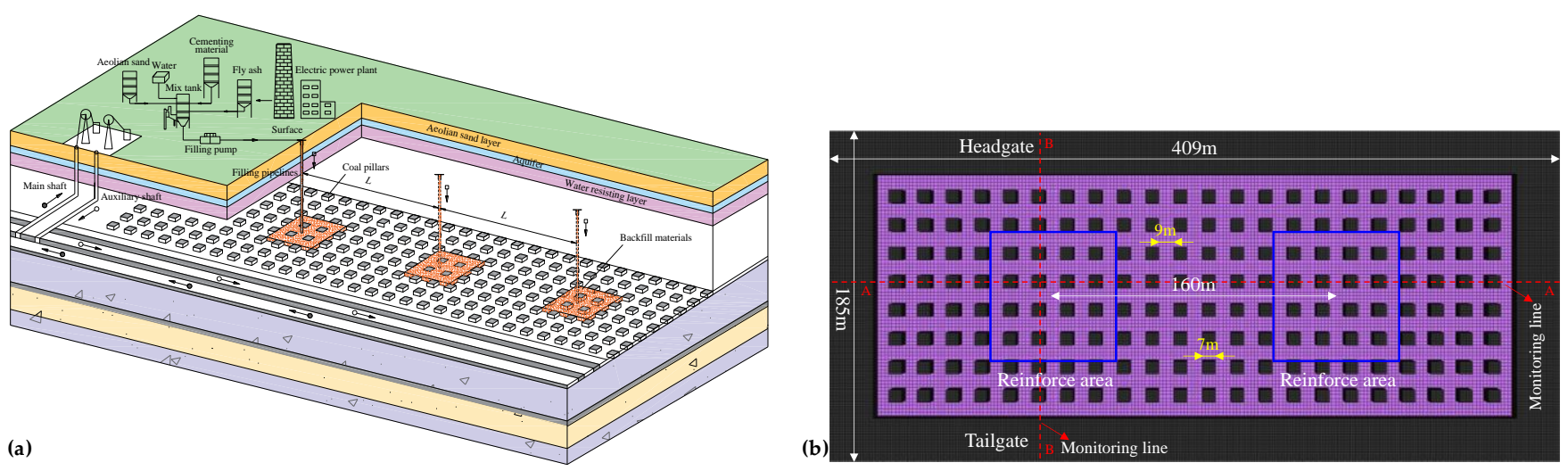

Figure 12. Principal scheme of reinforcement method of residual coal pillars in room mining: (a) technical schematic, (b) reinforced coal pillar model size.

\subsection{Analysis of Results}

The characteristics of the plastic zone and stress distribution in stope via the reinforcement method of residual coal pillars in room mining were obtained through numerical simulation, as shown in Figure 13. The middle profile of left-behind coal pillars' stress was selected to analyze room mining development and stability, as shown in Figure 14. 

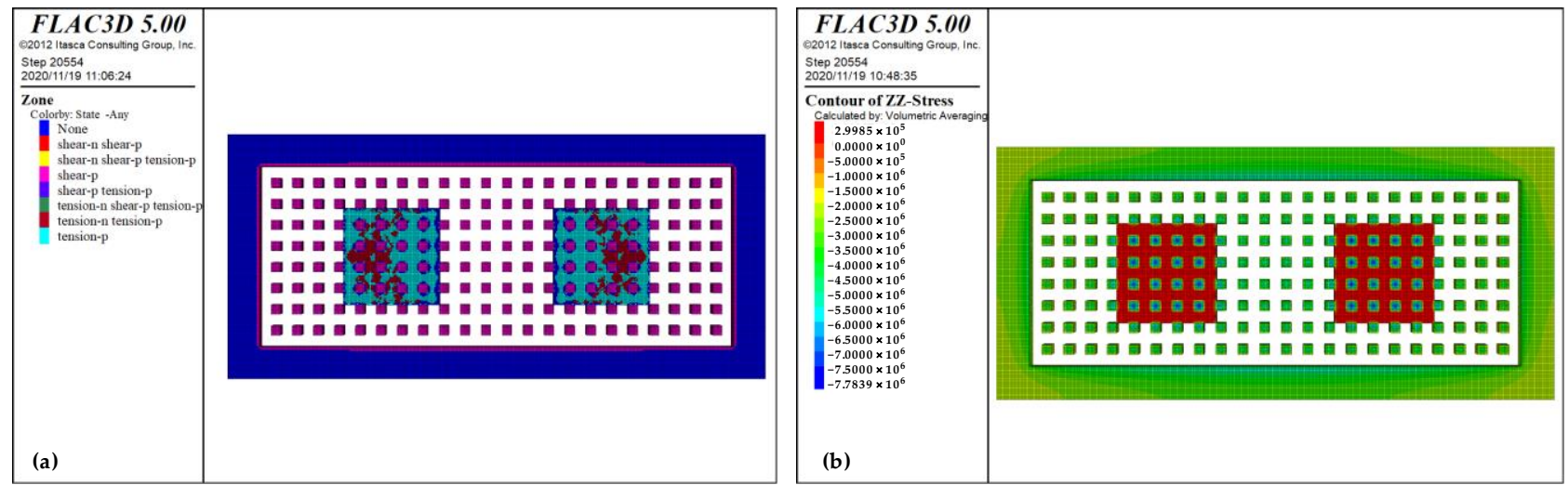

Figure 13. Characteristics of the plastic zone and stress distribution in stope via the reinforcement method: (a) the plastic zone, (b) the stress distribution.
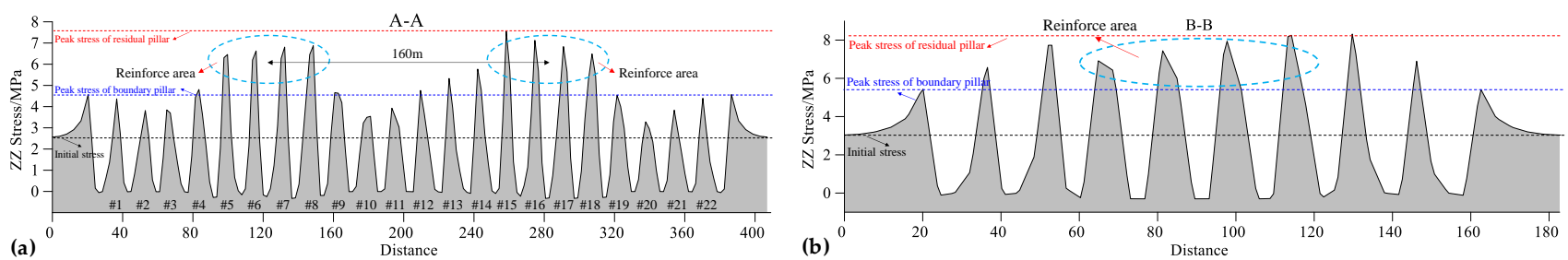

Figure 14. Profile of stress distribution characteristics of coal pillars in stope via the reinforcement method: (a) A-A profile, (b) B-B profile.

The results show that the stope stress can be effectively transferred, the instability and failure of the coal pillar can be reduced after the coal pillar area is backfilled and reinforced with average peak stress of 7.8 MPa. Because of the backfilling body's effective bearing function, the overlying strata's damage and movement can be effectively restricted. The monitoring of the vertical subsidence curve of key aquiclude strata is shown in Figure 15.

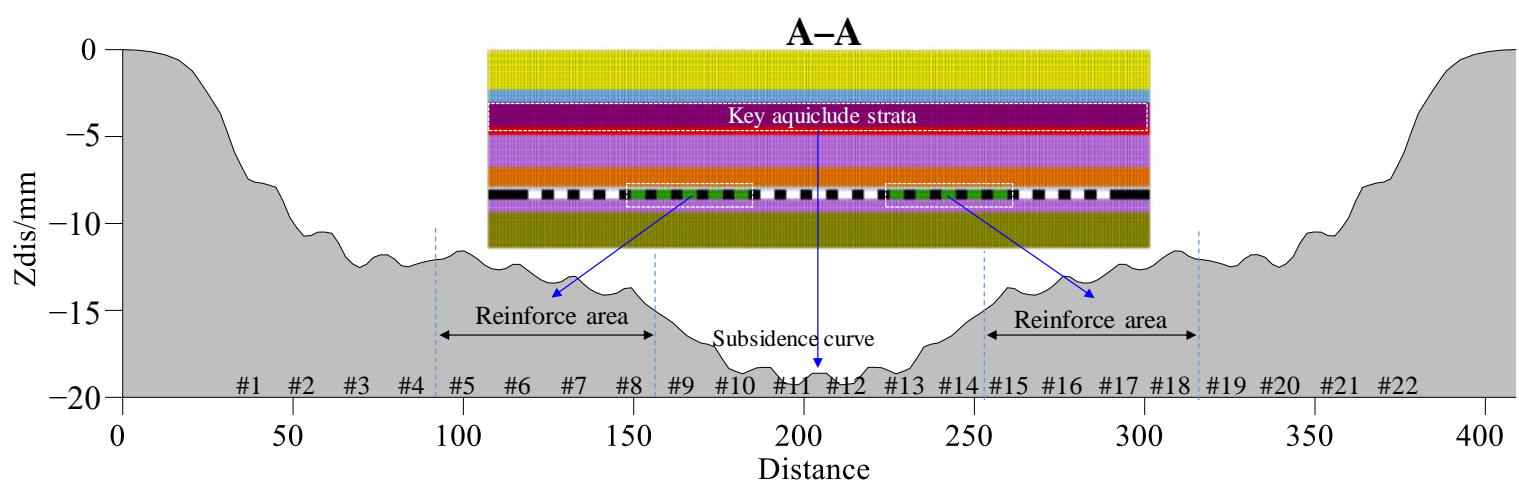

Figure 15. Measured vertical subsidence curve of key aquiclude strata via the reinforcement method.

After using the reinforcement method of residual coal pillars in room mining, the vertical subsidence curve of key aquiclude strata, which showed the characteristics of regional differences, was constructed. Eventually, the vertical subsidence deformation of key aquiclude strata in the Pliocene series of Neogene reached about $19 \mathrm{~mm}$, of which the value is negligible versus the thickness $(15 \mathrm{~m})$ of key aquiclude strata. Without the reinforcement, the maximum vertical subsidence is more than $850 \mathrm{~mm}$ after the coal pillars failure according to the field measurement. Although the residual coal pillars underwent plastic zone failure, the long-term stability of the overlying key aquiclude strata could be controlled by the regional backfilling body and coal pillars' action. 


\section{Discussion and Conclusions}

Given the roof dynamic disaster and environmental damage hazards caused by the instability of coal pillars in room mining in the western ecological fragile mining area, the main modes and patterns of coal pillar failure in room mining were investigated in this paper. The plastic zone and stress variation characteristics of the coal pillar in stope after the coal pillar size variation and the progressive instability failure of the coal pillar were analyzed in detail through numerical simulation. The reinforcement method of residual coal pillars in room mining and simulation plans were then proposed. The stability control effect of residual coal pillars and key aquiclude strata using this method were further studied. In the actual mining activities, due to the coal seam dip angle and the irregular size of residual coal pillar in room mining, it is necessary to control the reinforcement area in the actual process of backfilling reinforcement. On the other hand, backfilling materials' fluidity and mechanical properties are closely related to the composition and proportion of materials, such as aeolian sand, gangue, fly ash, cement, etc. Furthermore, in the actual backfilling process, the backfill body must not be completely regular and connected to the roof. A position close to the vertical backfilling pipeline connected to the top can be used, which is different from this paper's theoretical research. After filling, the space between ground pump backfilling stations is another key factor to control the stability of overlying key aquiclude strata, which is vital for protecting water resources and the surface environment. Therefore, it will be useful to investigate this method's reliability and effect in the future by performing long-term data analysis associated with monitoring on the surface.

Based on the above, the conclusions in this paper are as follows:

(1) Based on the numerical simulation results, the influence of different sizes of coal mining pillars and progressive instability failure of coal pillar on strata movement in stope was studied. The numerical simulation of room mining shows that the coal pillar's failure gradually occurs from the outside to the inside. The peak stress on the coal pillar increases from 6.7 to $10.5 \mathrm{MPa}$ with a size drop from $9 \mathrm{~m} \times 9 \mathrm{~m}$ to $7 \mathrm{~m} \times 7 \mathrm{~m}$, after which the peak stress decreases to $8.0 \mathrm{MPa}$ with a pillar size of $5 \mathrm{~m} \times 5 \mathrm{~m}$. With a gradual increase in the scope of small-sized coal pillars, after the coal pillars failed, the overlying load transferred to the large coal pillars nearby. With an increase in the number of unstable coal pillars, the roof's effective bearing capacity will deteriorate. The suspended roof area will increase; when the breaking limit is reached, the roof will collapse in a large area. It will bring dynamic disasters of roof movement and surface subsidence, and other environmental damages.

(2) The technology of cemented paste backfilling from the ground and reinforcement of residual coal pillars are put forward. The numerical simulation model is established to study the strata movement characteristics and analyze the stability degree of residual coal pillar and key aquiclude strata in the Pliocene series of Neogene. In this study, the results provide ideas and methods for the long-term stability control of coal pillars in room mining of coal resources and protect the environment in the local ecologically fragile mining area.

Author Contributions: Conceptualization, H.L. and Q.S.; methodology, H.L. and Q.S.; software, H.L. and Z.W.; investigation, H.L.; formal analysis, H.L. and Q.S.; resources, H.L., Q.S., N.Z. and Z.W.; data curation, N.Z.; writing—original draft preparation, H.L. and Q.S.; writing—review and editing, H.L., Q.S., N.Z. and Z.W.; visualization, H.L.; supervision, N.Z. All authors have read and agreed to the published version of the manuscript.

Funding: The authors appreciate the financial support of this work provided by the Future Scientists Pro-gram of China University of Mining and Technology (2020WLKXJ006) and the Postgraduate Re-search \& Practice Innovation Program of Jiangsu Province (KYCX20_2012).

Institutional Review Board Statement: Not applicable.

Informed Consent Statement: Not applicable.

Data Availability Statement: Data sharing not applicable. 
Acknowledgments: The authors would like to thank the editors and reviewers for their hard work and professional suggestions that helped improve the quality and value of this study.

Conflicts of Interest: The authors declare no conflict of interest.

\section{References}

1. Xie, H.P.; Wang, J.H.; Shen, B.H.; Liu, J.Z.; Wu, J. New idea of coal mining: Scientific mining and sustainable mining capacity. J. China Coal Soc. 2012, 37, 1069-1079.

2. Wang, F.T.; Tu, S.H.; Li, Z.X.; Tu, H.S.; Chen, F. Mutation instability mechanism of the room mining residual pillars in the shallow depth seam. J. Min. Saf. Eng. 2012, 29, 770-775.

3. Liu, C.Y.; Wei, J.Q.; Wan, J.Z.; Liang, G.F. Strata behaviors and roof monitor of room-and-pillar system. J. China Univ. Min. Technol. 2002, 31, 61-64.

4. Xie, X.Z. Study on the characteristics of strata behavior in shallow seam longwall mining under the room-and-pillar mining goaf. J. China Coal Soc. 2012, 37, 898-902.

5. Wang, L.G.; Wang, Z.S.; Huang, J.H. Prediction on the height of water-flowing fractured zone for shallow seam covered with thin bedrock and thick wind-blown sands. J. Min. Saf. Eng. 2012, 29, 607-661.

6. Adibee, N.; Osanloo, M.; Rahmanpour, M. Adverse effects of coal mine waste dumps on the environment and their management. Environ. Earth Sci. 2013, 70, 1581-1592. [CrossRef]

7. Dong, S.C.; Samsonov, S.; Yin, H.W.; Yao, S.P.; Xu, C. Spatio-temporal analysis of ground subsidence due to underground coal mining in Huainan coalfield. China Environ. Earth Sci. 2015, 73, 5523-5534. [CrossRef]

8. Ghasemi, E.; Ataei, M.; Shahriar, K. Prediction of global stability in room and pillar coal mines. Nat. Hazards 2014, 72, 405-422. [CrossRef]

9. Zhang, J.X.; Sun, Q.; Zhou, N.; Jiang, H.Q.; Germain, D.; Abro, S. Research and application of roadway backfill coal mining technology in western coal mining area. Arab. J. Geosci. 2016, 9, 1-10. [CrossRef]

10. An, B.F. Controlling Mechanism of Surround Rock Stability in Recovering Room Mining Standing Pillars by Consolidated Solid Backfilling Mining; University of Technology: Xuzhou, China, 2016; pp. 1-124.

11. Fang, K. Research on Principal Technology of Recovering Room Coal Pillar with Combined Artificial Pillar and Solid Backfill Mining; University of Technology: Xuzhou, China, 2016; pp. 1-68.

12. Sun, Q.; Zhang, J.X.; Zhou, N. Study and discussion of short-strip coal pillar recovery with cemented paste backfill. Int. J. Rock Mech. Min. Sci. 2018, 104, 147-155. [CrossRef]

13. Liu, H.; Lei, S.G.; Deng, K.Z.; Yu, X.; Wang, Y.X. Research on ground fissure treatment filling with super-high-water material. Int. J. Rock Mech. Min. Sci. 2014, 39, 72-77.

14. Zhang, J.X.; Huang, P.; Zhang, Q.; Li, M.; Chen, Z.W. Stability and control of room mining coal pillars-taking room mining coal pillars of solid backfill recovery as an example. J. Cent. South Univ. 2017, 24, 1121-1132. [CrossRef]

15. An, B.F.; Zhang, J.X.; Li, M.; Huang, P. Stability of pillars in backfilling mining working face to recover room mining standing pillars. J. Min. Saf. Eng. 2016, 33, 238-243.

16. Zhang, M.; Jiang, F.X.; Li, J.Z.; Jiao, Z.H.; Hu, H.; Shu, C.X.; Gao, H.J. Stability of coal pillar on the basis of the co-deformation of thick rock strata and coal pillar. Rock Soil Mech. 2018, 39, 705-714.

17. Tan, Y.; Guo, W.B.; Zhao, Y.H. Engineering stability and instability mechanism of strip Wongawilli coal pillar system based on catastrophic theory. J. China Coal Soc. 2016, 4, 1667-1674.

18. Jaiswal, A.; Sharma, S.K.; Shrivastva, B.K. Numerical modeling study of asymmetry in the induced stresses over coal mine pillars with advancement of the goaf line. Int. J. Rock Mech. Min. 2004, 41, 859-864. [CrossRef]

19. Bertuzzi, R.; Douglas, K.; Mostyn, G. An approach to model the strength of coal pillars. Int. J. Rock Mech. Min. 2016, 89, 165-175. [CrossRef]

20. An, B.F.; Yu, J.W.; Wu, G.S.; Wang, C.L. Plastic zone and stress evolution of pillars in working face with solid backfilling mining to recover room coal pillars. J. Min. Saf. Eng. 2019, 36, 609-616. 